\title{
Rejoicing the visual richness in mosque architecture in Khyber Pakhtunkhwa, Pakistan.
}

Published:

25-09-2021

Accepted:

25-08-2021

Received:

25-07-2021
Ar. Iftikhar Ali

Assistant Professor, Department of Architecture, Hazara University, Mansehra

Email: archiftikharali@hu.edu.pk

Ar. Mir Wali Shah

Assistant Professor, Department of Architecture, Hazara

University, Mansehra

Email:mwshah@gmail.com

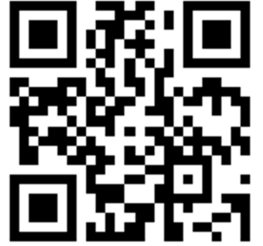

\section{Abstract}

Mosque construction and expansion in the modern world is a significant achievement, particularly in Muslim majority communities. A mosque is a single building that serves as a center for both religious and social activities. Mosques must be designed to reflect religious beliefs, social values, and the local environment. Aside from being a functional location for salah (prayer), it also has symbolic value as a representation of Muslim religious beliefs and life after death. This study is focused on the visual richness of the mosque's architectural design and the identification of those elements that adds fullness to the experiential qualities of the mosques. This research uses a case study approach to evaluate mosque projects in various locales across Khyber Pakhtunkhwa, Pakistan. Various architectural features of mosques were recognized used for adding visual richness in design and then classified based on their historical significance. A comparison of mosques' design architectural elements is carried out. The findings point to a consistency in the incorporation of functional elements, while the aesthetic elements are more locale-specific. The aesthetic elements need to be treated as an important component of mosque design. This work has further elaborated the need for the re-establishment of the importance of aesthetic values in contemporary mosque architecture and recommended its revival.

Keywords: Mosque architecture, visual richness, decoration, aesthetics elements, Khyber Pakhtunkhwa

\section{INTRODUCTION}

\subsection{Historical Background:}

A mosque, or masjid in Arabic, is a gathering place for Muslims to pray. In Islamic architecture, it is a significant architectural type. Mosques are the first buildings to be built in Islamic architecture. It is still a significant aspect of Muslim communities and institutions. Due to its multiple noteworthy architectural characteristics, it also serves as a symbol of the Muslim community. From Madinah's first mosque, the Prophet (SAW) Mosque, to the present day, the mosque's core architectural characteristics

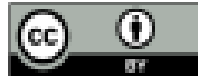


have undergone significant transitions and transformations. ${ }^{1}$ To begin with, the mosques were very austere in design, entirely functional, and lacked any aesthetic richness. However, other features remained constant, such as orientation (Qibla direction), separation of secular and spiritual places, and transparency in the use of various venues. The Qibla wall, Minaret, Mehrab, Prayers Hall, Mehrab, Minbar, Courtyard or Sehn, and Ablution area are all important architectural characteristics of the mosque. ${ }^{2}$

\subsection{Research Questions:}

In this study attempt has been made to answer the following key research questions:

1. Enumeration of the main characteristics that make up the essence of mosque architecture.

2. Identification of the main aesthetic elements that contribute to its richness in the context of Khyber Pakhtunkhwa.

\subsection{Research Methodology:}

A case study approach was used for this paper, with more than 50 mosques in different cities in Khyber Pakhtunkhwa being investigated. Based on architectural details, essence, and aesthetic elements specific to their location, only five mosques were chosen for this article. Mosque architecture's categorized functional and aesthetic elements are compared in the study. In addition, a critical assessment of the current trend in mosque architecture is made to adopt the new form and features. Furthermore, a critical appraisal of the present trend in mosque architecture is done for adopting the new form and features for it.

\section{MOSQUE ARCHITECTURE}

Mosques must symbolically depict Almighty Allah's superiority and it is also expected that the mosque will have an understandable, spiritual, and tranquil setting that entices the believer's senses to be closely attached to their Creator. This characteristic is portrayed semantically in Islamic architecture by using the highest grade of aesthetics. While in Islamic architecture the use of the most intricate Motifs and Ornamentation denotes the greatest level of aesthetic value. In mosque architecture, ornamentation is a combination of Islamic art, religious beliefs, and the existence of localized traditions. In terms of shape, material, scale, and time, the ornamentation concept is extremely malleable. The ornamentation in mosques varies by region, yet there are some parallels due to the shared religious basis, symbolizing unity in variety ${ }^{3}$.

\subsection{Characteristics of Islamic ornamentation:}

In Islamic architecture, religious values are accentuated to the greatest extent possible. A harmonious coexistence between believers and their constructed environment has always been one of the primary goals of traditional Islamic architecture. This aspect is highly valued in mosques when they are designed in terms of assisting the user of the space, while the 
mosques' inner ambiance is treated in such a way that it invites and welcomes whoever enters this environmental context.

\subsection{Geometrical Patterns}

The usage of endless patterns in the mosque, which is the first characteristic of Islamic adornment, is a direct reflection of the Creator, Almighty Allah's, infinity. Varied patterns with different interconnecting shapes and scales are created using geometry as a base. The inclusion of floral or vegetation in the foreground then complements the basic geometric patterns. These vegetal or floral motifs are usually based on geography and tradition. Geometry and motifs are utilized in two-dimensional patterns or non-structural three-dimensional arabesque on the numerous individual features of the mosque, such as the Minbar, Mehrab, Minar, or Qiblah wall. These geometric patterns have been purposefully subordinated to symbolize the Almighty Allah's infinite power.

\subsection{Verses of Holy Quran}

The second tier of embellishment is made up of Quranic verses that have been styled into a work of Islamic art. Islamic Calligraphy is the name given to this piece of art. It comes in a variety of forms and styles, with the primary goal of being used as a work of art while also conveying a message or mandate to believers. It's the ideal blend of aesthetic value and effective message conveyance from the Holy Quran and Hadith.

In mosques, ornamentation is utilized to emphasize the presence of Almighty Allah, and His creations are there to commemorate His infinity. Mosques are symbolic representations of Islam, which is a magnificent faith. When we enter mosques, we are entering the house of Almighty Allah, AlJamel, (The Beautiful), hence the mosques must be beautiful and ingrained with the highest qualities of aesthetics at all levels. The Great Mosque of Damascus, for example, represented the paradise garden with admirable features of motifs and patterns, which was the primary concept of all mosques built during the medieval eras.

It is a unique character of Islamic art, carrying the aesthetic beauty in its various styles while at the same time used to convey the commandment of Allah from the Holy book of Quran, a Divine wording that cannot be changed, paraphrased, solicited in the classical Arabic language. ${ }^{4}$ As human figurative art cannot be used in mosques, Muslims artists created and developed various styles for getting exhibited their eternal love for their Creator, in using the Quranic verses on the surface embellishment. ${ }^{5}$

\subsection{Surface Adornment:}

The third most prominent characteristic of Islamic Architecture is surface adornment, which is purely attributable to the Islamic world's cultural influence. The mihrab, which is used to point to the qiblah, is a feature of mosques that has gotten a lot of attention for its surface ornamentation portrayal for symbolically guiding to Allah ${ }^{6}$. The minbar, from which the 
imam delivers the message "khutba" in Friday prayer, is the second in the row, with its surfaces decorated with special artistic appearances. Both of these mosque features are stacked with complexity at multiple levels of visually imparting messages to attendees.

Additional to the above mentioned to the first three In Islamic Architecture, architects used surface decoration with creative use of light, color, texture, and shadows to exhibit and celebrate the authority of their Creator. ${ }^{7}$ When we look at Islamic art and architecture as a whole, we can see how it can focus on numerous tiers of meaning and adornment, depicting the story inside the story within the story of the motif within the motif within the motif, reflecting the complexity at multiple levels of symbolism. This complexity may be seen in many of the Quran's literary constructions, which can be viewed as art within Islamic religious art and architecture.

\section{MOSQUES IN KHYBER PAKHTUNKHWA}

The appreciation of architectural beauty is only used in the functional layout of the primary functional features, such as the prayer hall, courtyard, and ablution area, in today's mosques. While the aesthetic components that are crucial to strengthen the act of prostration and faith enactment in the users are immediately ignored. These characteristics have grown over time to enrich believers' experiences and aid them in becoming directly bonded to their Almighty Allah.

\subsection{Masjid Mahabat Khan Peshawar:}

The Mahabat Khan mosque is located in the historical city of Peshawar and is a $17^{\text {th-century Mughal era mosque }}{ }^{8}$. It is unique due to its use of colors, arches, roof, and geometrical patterns. There are many articles written on its feature in scholarly journals, but here our main focus is on the use of aesthetic elements that are used to attract the user's attention.

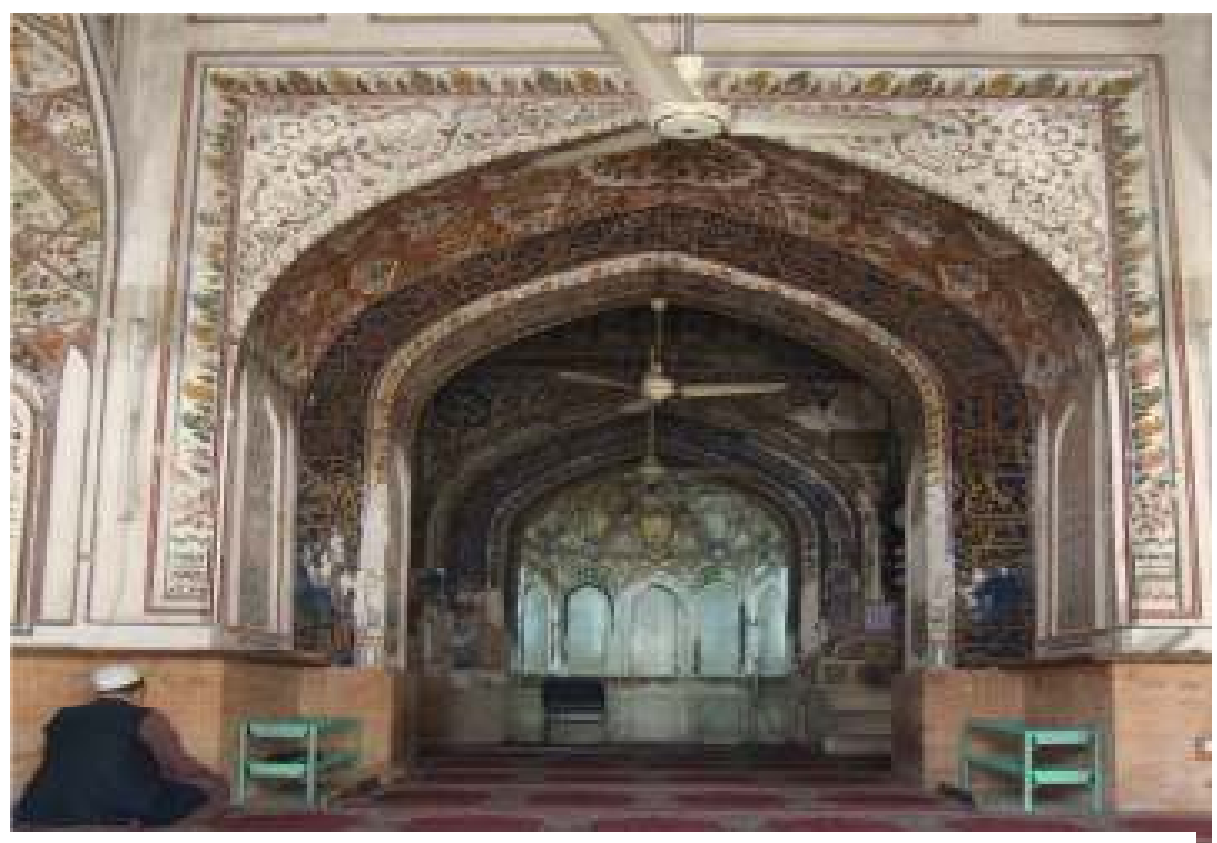

Figure \# 01 Main Arch in central compartment 
The main Mehrab features a much deeper arch in the main central chamber. Almost the entire interior surface is covered with panels of various sizes, shapes, and designs that are embellished with mural paintings. The walls and ceiling are adorned with magnificent frescos of floral motifs, leaves, vases, and deeply entwined foliage 9 . The Holy Quran's verses are likewise superbly written. The decoration was most likely reconstructed according to the original scheme in the early twentieth century. (Fig \# 2, 3, 4, 5, 6).
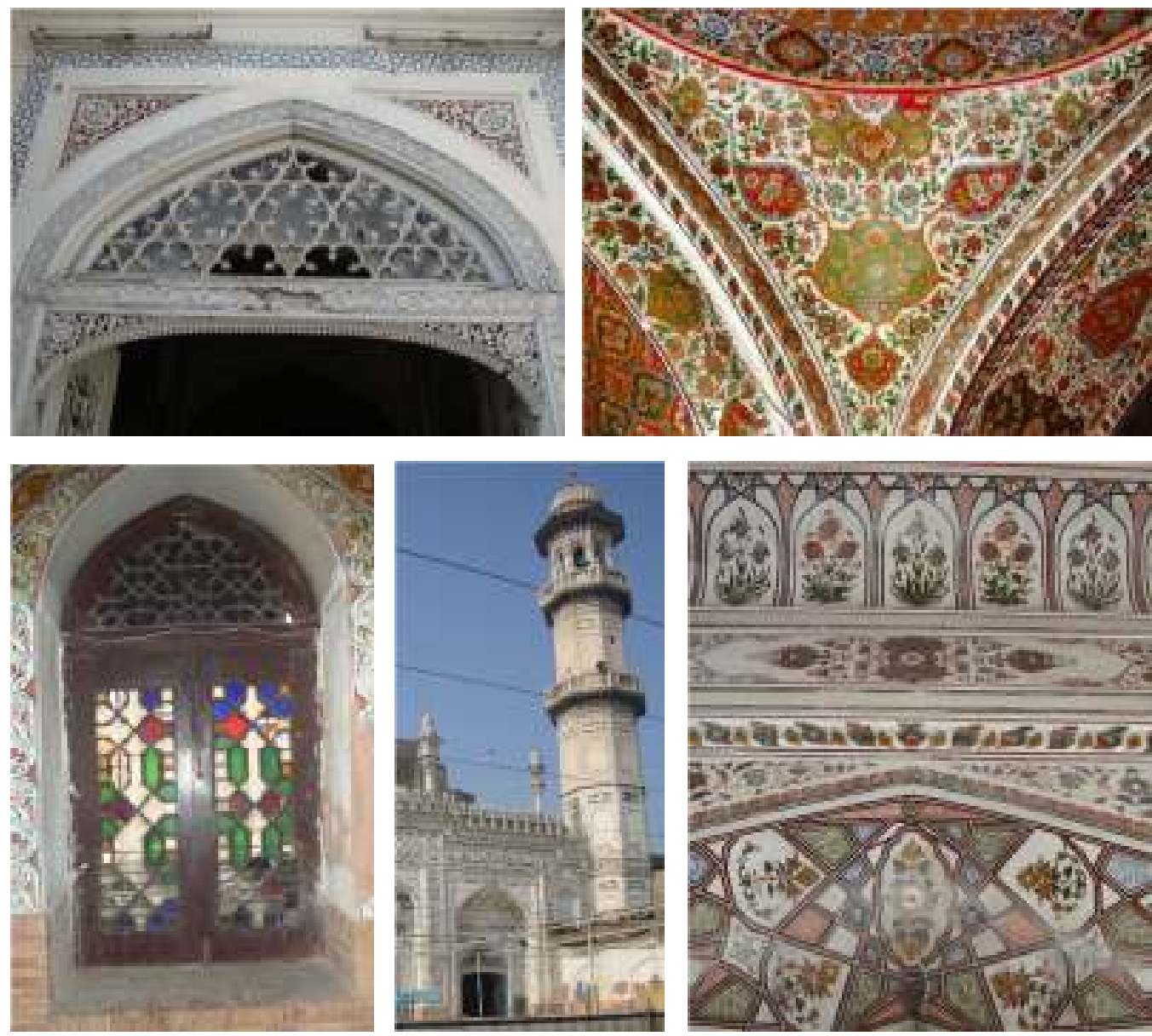

Figure 2, 3, 4, 5, and 6: Floral work in interior, ornamentation, Patterns and Painting.

\subsection{Ilyasi Masjid Abbottabad:}

The Ilyasi Masjid is Abbottabad's oldest and most historically significant mosque. It was erected between 1927 and $1932^{10}$. This is one of the best in terms of architectural and distinctive buildings. With its white gleaming grandeur, architectural beauty, and intimidating construction, the mosque is a sight to behold. The mosque's exterior features exquisite carvings that appear to be the work of artists, (Fig \# 7, 8, 9). 

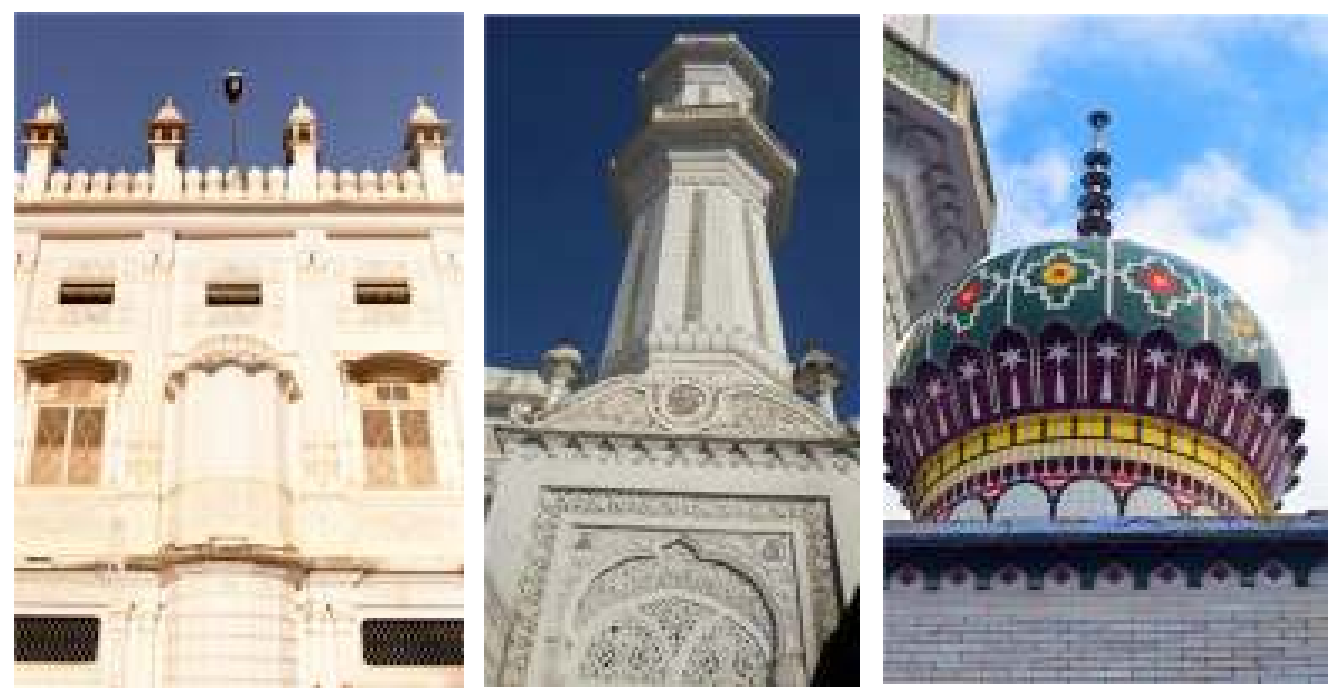

Figure \# 7, 8, 9: IL YASI Masiid Abbottabad Decorative Works at

\subsection{Ancient mosque in Swat:}

The 1,000 years -old mosque known as Lwarrey Jumat in Khwazakhela town is known for its architectural grandeur and wood carving masterpieces (Figure \# 10).

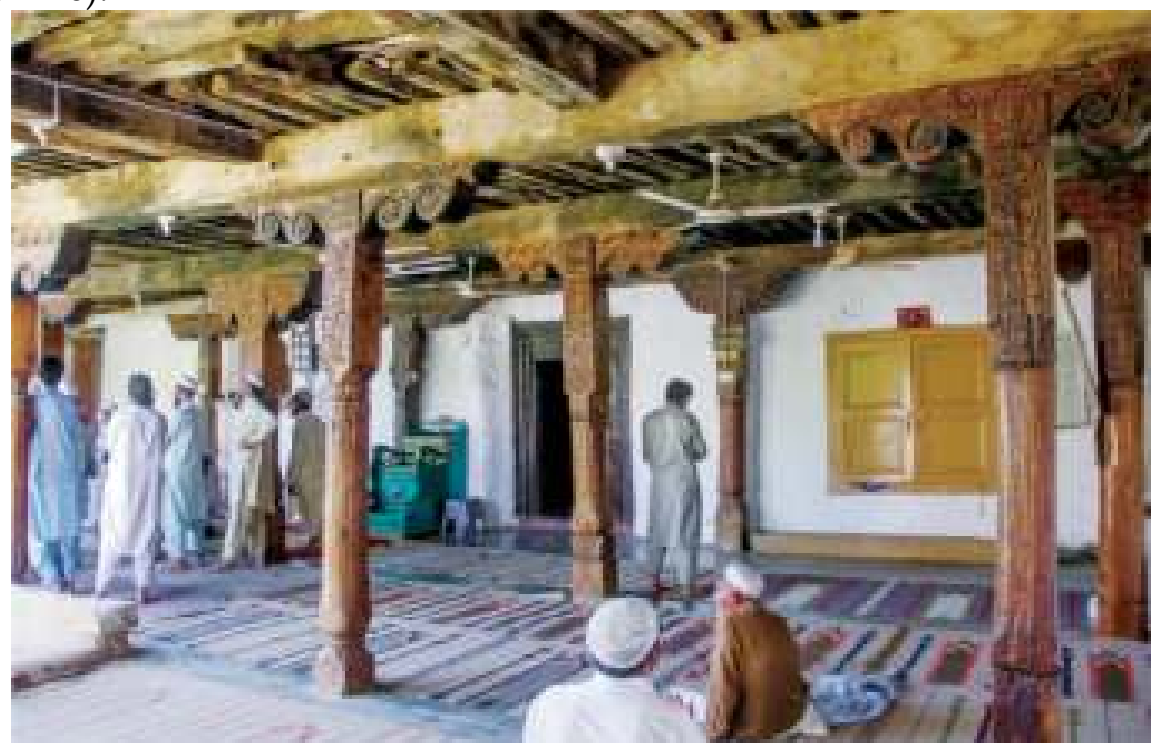

Figure \# 10, Wooden Columns with carving

According to the locals, the army of Mahmood Ghaznavi built it after defeating the Hindu army in the eleventh century. Its antique structure is oneof-a-kind, complete with carvings, ornamentations, and geometrical patterns. Traditional ornamentation includes flower designs and motifs carved onto wooden beams and pillars. Floral carvings in the Swati style are interspersed with Persian, Greek, and Buddhist themes on the pillars. The mosque's 
architectural grandeur and high-class traditional wood carving of the early Swatis continue to draw art and architecture enthusiasts ${ }^{11}$.
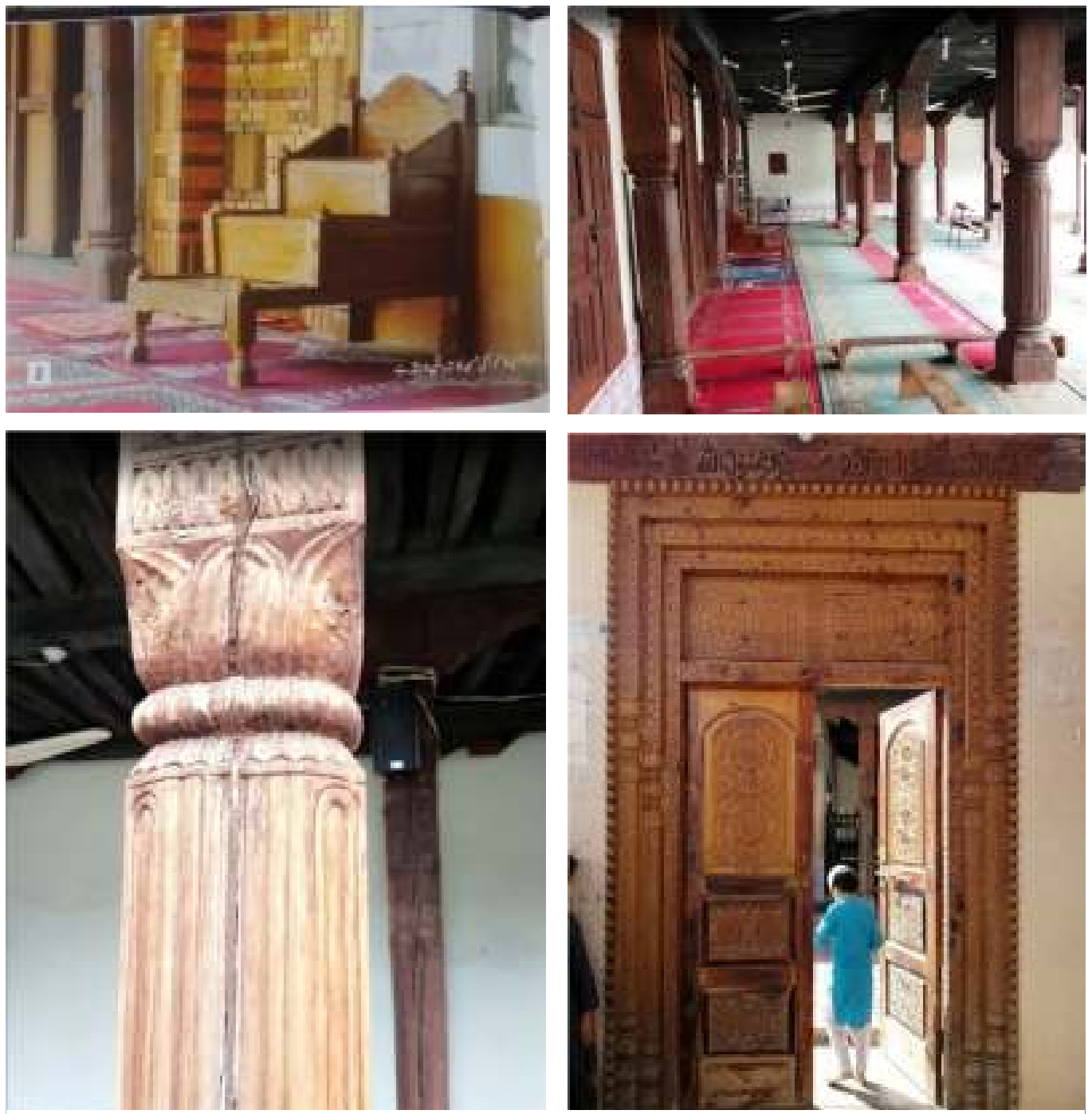

Figure: 11,12,13 and 14 Carving, Patterns Verses of Holy Quran and Calligraphy

\subsection{Sheikh Imam Uddin Tomb and Mosque Palosai, Peshawar:}

The 400-year-old Mughal-era mosque under the name of Sheikh Imam Uddin at Palosai village is a superb example of Mughal era architecture with its painted ornamented walls. His disciples, Sheikh Abdul Razzaq and Sheikh Abdul Haq, began building on the mausoleum in 1652AD and finished it in 1658. The main entrance is on the south side and leads directly into the basement; the magnificent tomb is on the veranda, which is surrounded by massive arches on all four sides. ${ }^{12}$ 


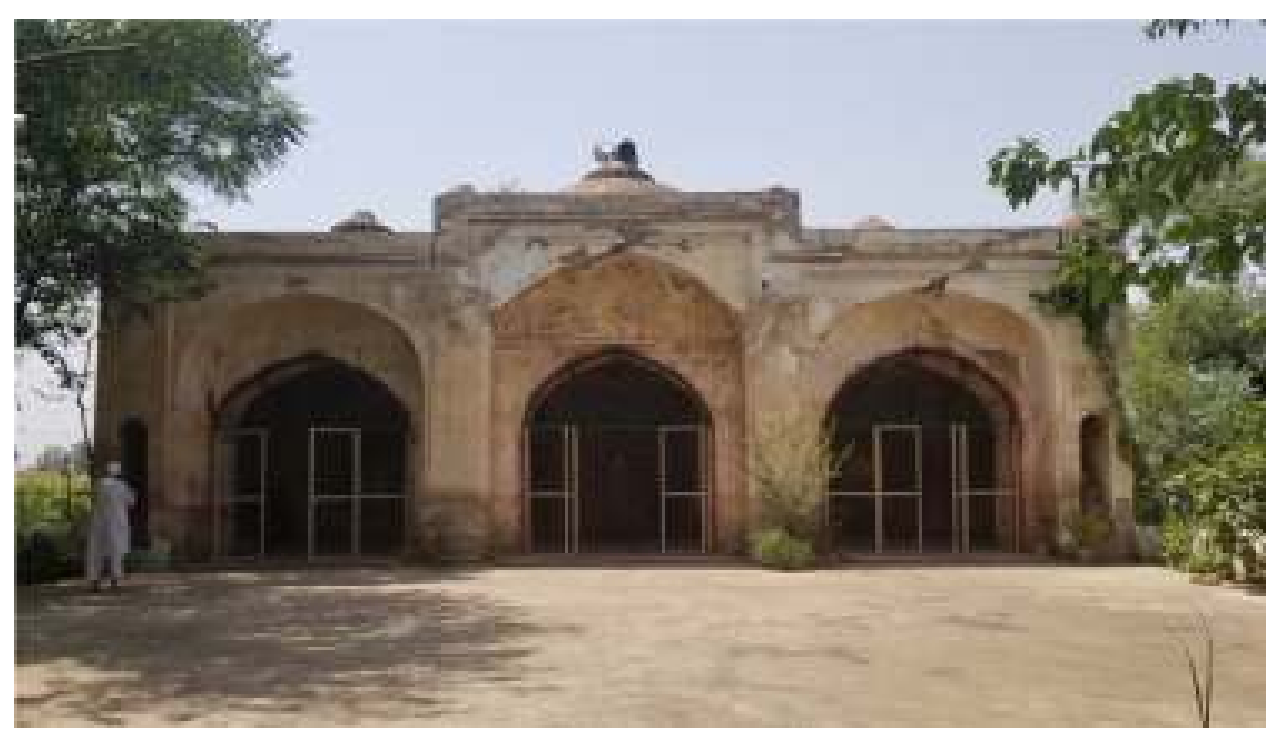

Figure: 15 Masjid Imam Ud Din, Palosai (Picture Source: Ar. Rabia Nouren)

A three-domed mosque stands to the west of the tomb. The mosque has three doors that open under lofty arches and are rectangular. The inside of the mosque, as well as the central doorway, are heavily painted in the same style as the tomb, indicating that the mosque and tomb were constructed at the same period. One of the oldest icons of our national heritage is this Mughal-era structure.
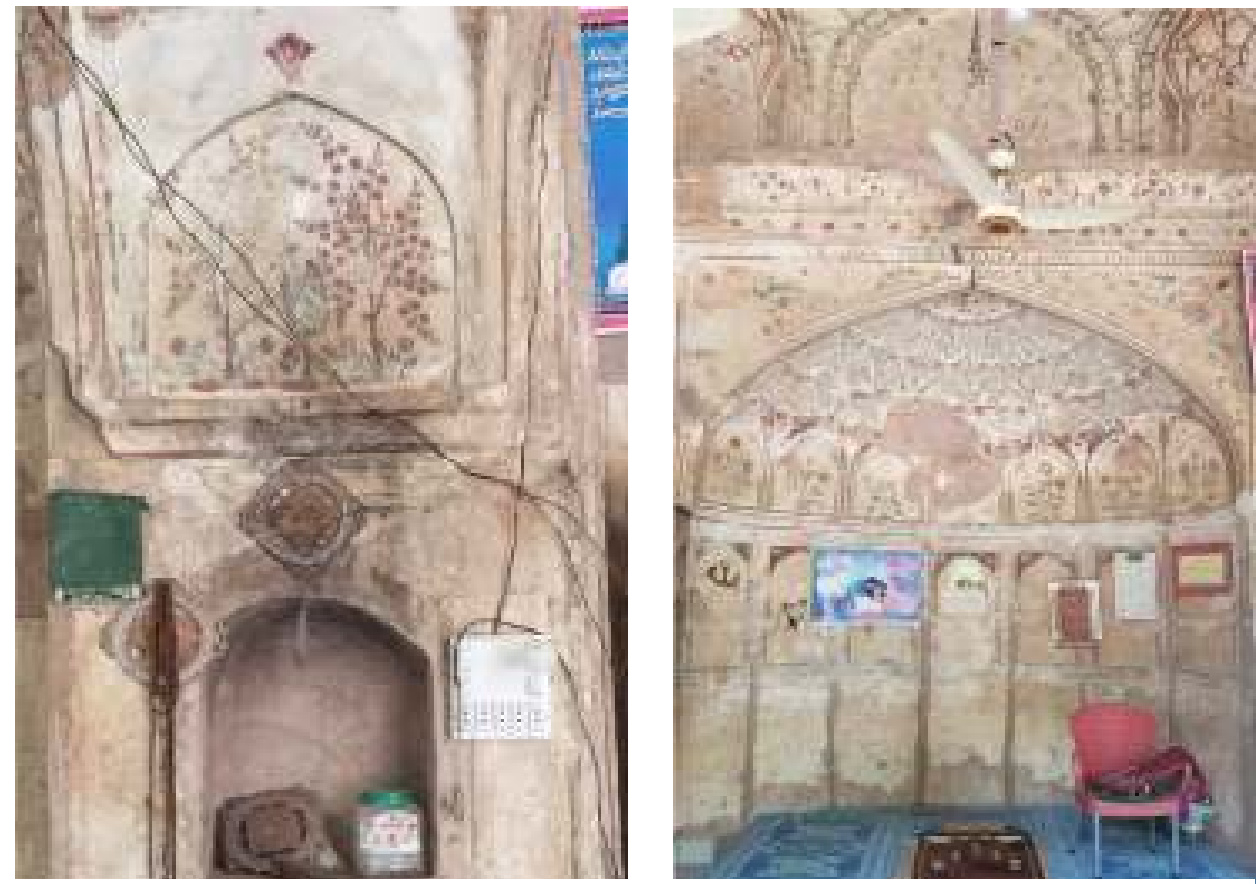

Figure: 16, 17 Floral work in interior, ornamentation, Patterns and Painting. 

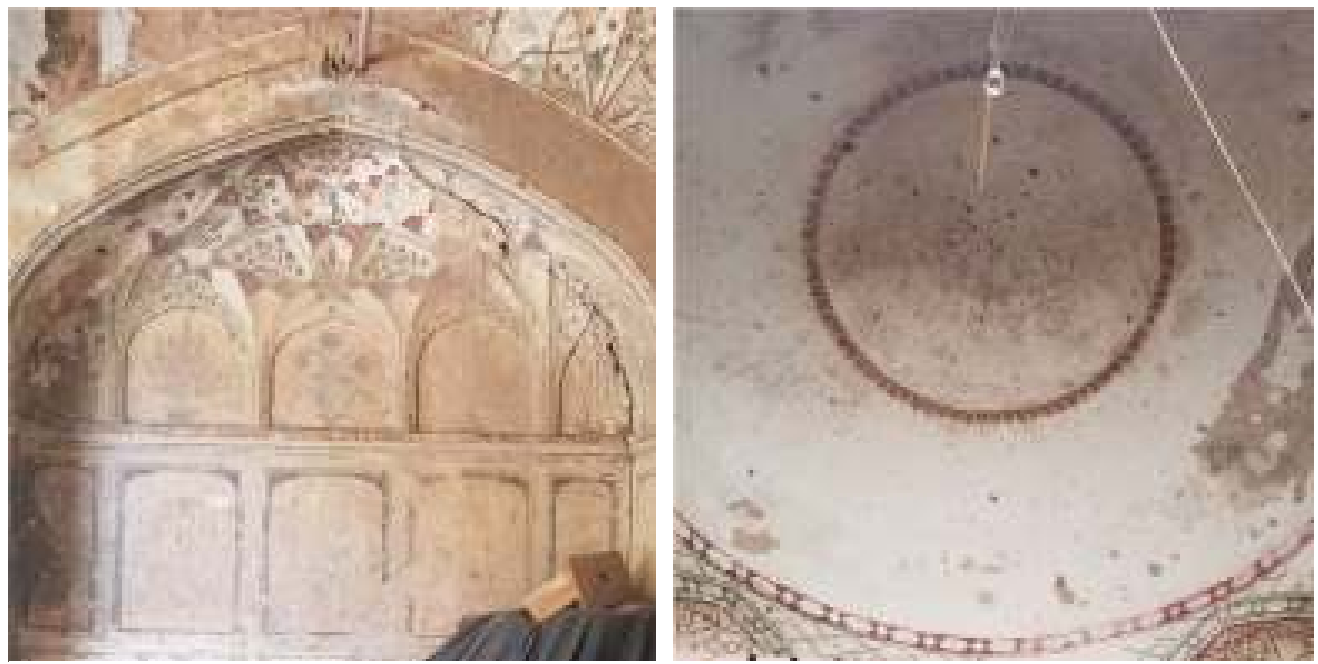

Figure: 18, 19 Geometrical Patterns and Painting. (Picture Source: Ar. Rabia Nouren)

\subsection{Hazara University Jamia Masjid:}

Known as Jamia Al-Malik Abdul Aziz bin Abdul Rahman (Islamic Center), Hazara University, Mosque Mansehra was built in 2015. The project consisted of the central Jamia Mosque for Hazara University campus in Mansehra after the 2005 earthquake.

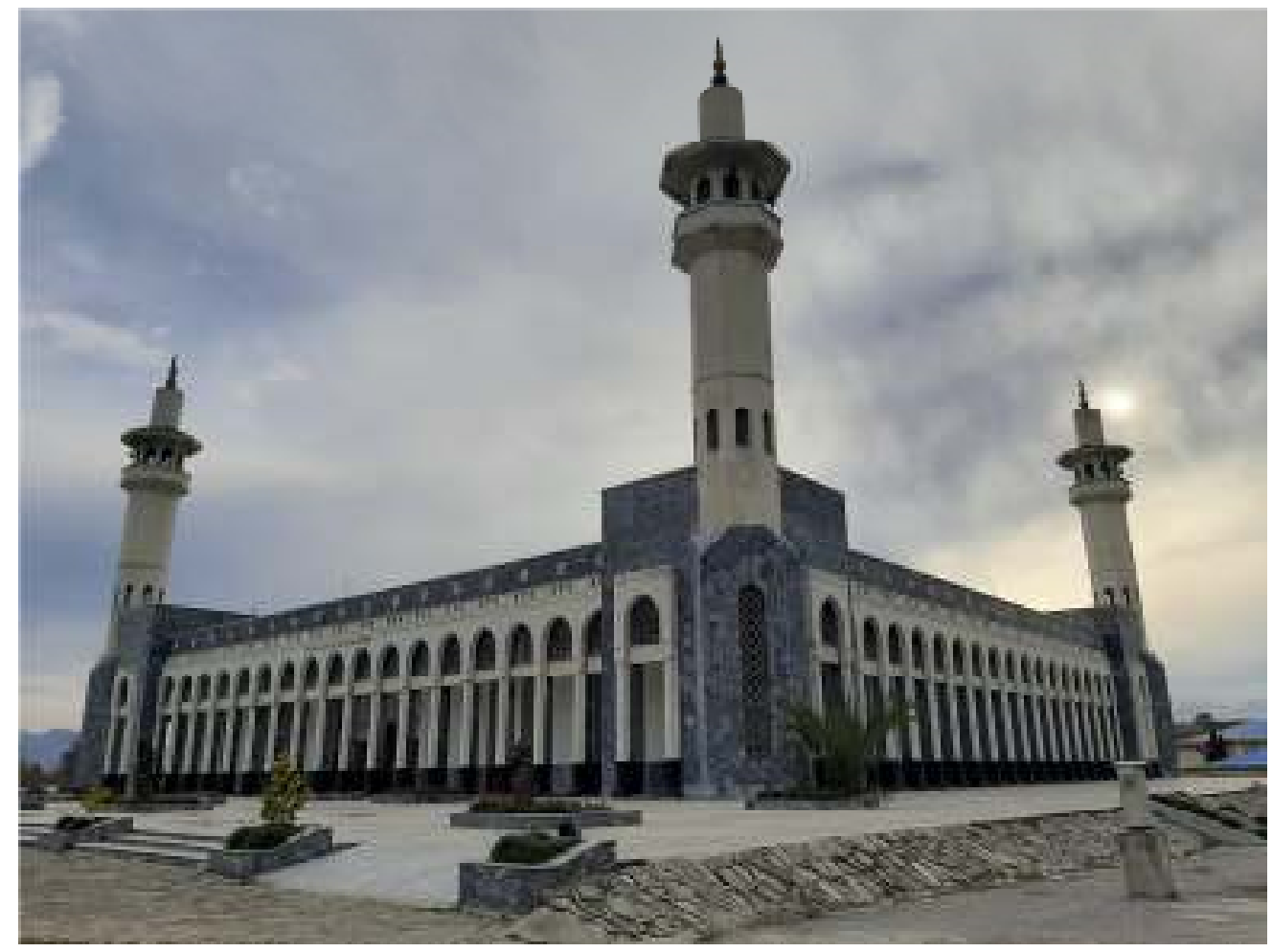

Figure \# 20. Hazara University Jamia Masiid (Picture source: Author) 
The large hall of the Contemporary Masjid is not full of decoration i.e. painting, ornamentation but the geometrical patterns, Calligraphy, and Verses of the Holy Quran are not highlight inside the masjid. They used the patterns on the floor and walls with simple colors and one theme in the whole masjid. Arcades outside the masjid with gray marble and white cemented. Calligraphy was used only to write the Allah Names outside the Veranda inside the circles.
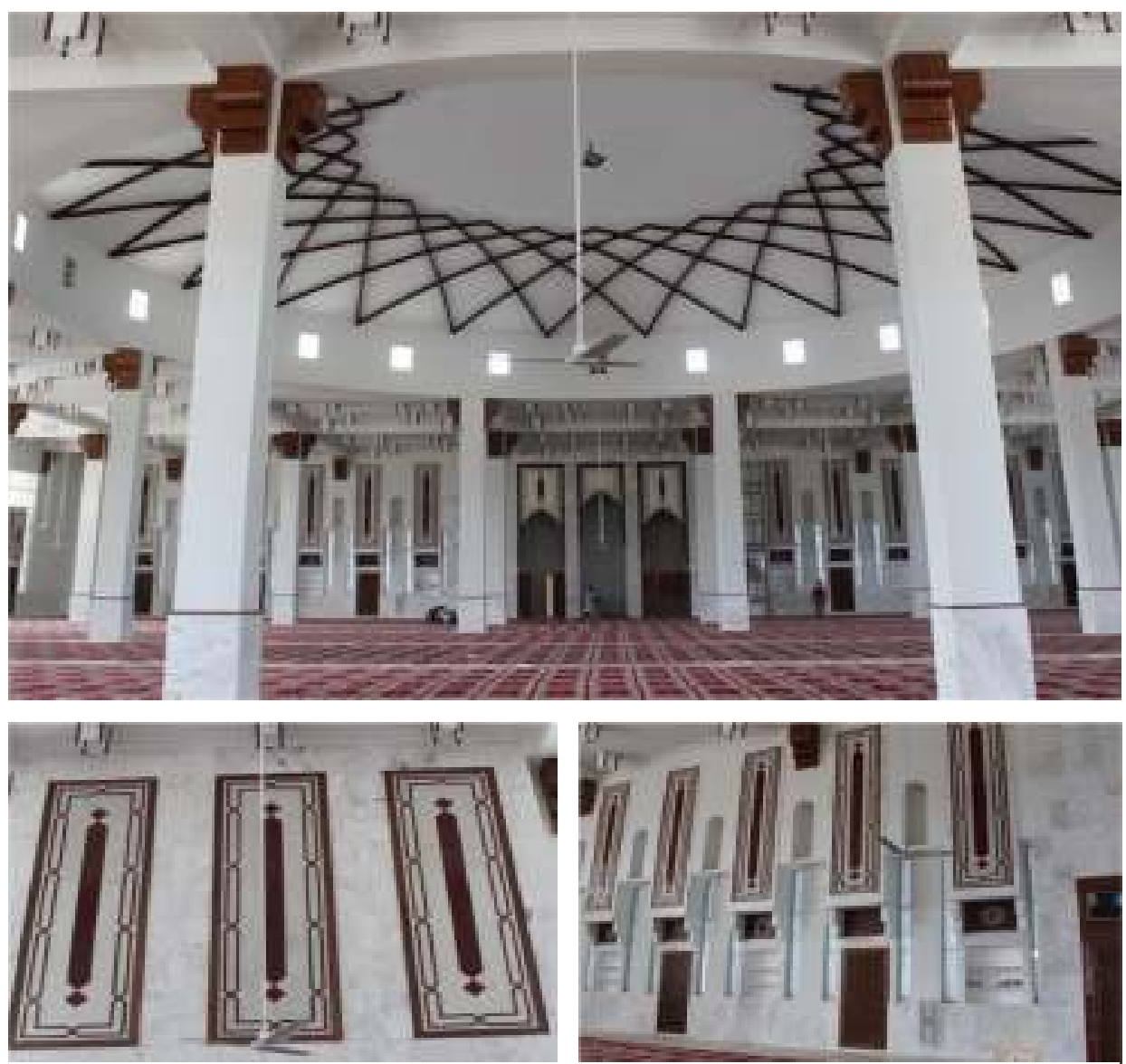

Figure: 21. 22. 23 Geometrical Patterns 


\section{COMPARATIVE STATEMENT OF THE ARCHITECTURAL ELEMENTS OF THE SELECTED MOSQUES}

A careful study of the elements present in all these five mosques was conducted. The overall architectural elements are categorized into two major typologies i.e. Functional or Major features and Aesthetic features. Table 01 is showing the presence of the functional elements present in these selected mosques.

\begin{tabular}{|l|c|c|c|c|c|}
\hline $\begin{array}{c}\text { Names/ } \\
\text { Architectural } \\
\text { Elements }\end{array}$ & $\begin{array}{c}\text { Masjid } \\
\text { Mohabat } \\
\text { Khan }\end{array}$ & $\begin{array}{c}\text { Shiekh } \\
\text { Imam u } \\
\text { din Masjid }\end{array}$ & $\begin{array}{c}\text { Lwarrey } \\
\text { Jumat }\end{array}$ & $\begin{array}{c}\text { Ilyasi } \\
\text { Masjid }\end{array}$ & $\begin{array}{c}\text { Hazara } \\
\text { University } \\
\text { Jamia } \\
\text { Mosque }\end{array}$ \\
\hline 1. Prayer Hall & $\checkmark$ & $\checkmark$ & $\checkmark$ & $\checkmark$ & $\checkmark$ \\
\hline 2. Veranda & $\checkmark$ & $\times$ & $\checkmark$ & $\checkmark$ & $\checkmark$ \\
\hline $\begin{array}{l}\text { 3. Courtyard } \\
\text { (Sehn) }\end{array}$ & $\checkmark$ & $\checkmark$ & $\checkmark$ & $\checkmark$ & $\times$ \\
\hline 4. Minbar & $\checkmark$ & $\checkmark$ & $\checkmark$ & $\checkmark$ & $\checkmark$ \\
\hline 5. Mehrab & $\checkmark$ & $\checkmark$ & $\checkmark$ & $\checkmark$ & $\checkmark$ \\
\hline 6. Minar & $\checkmark$ & $\times$ & $\checkmark$ & $\checkmark$ & $\checkmark$ \\
\hline 7. Dome & $\checkmark$ & $\checkmark$ & $\times$ & $\checkmark$ & $\checkmark$ \\
\hline
\end{tabular}

Table 01: Showing the Functional spaces of the mosques

The second type of elements identified to be adding the richness in these mosques are identified in table 02. It suggests that these elements are responsible for adding, serenity to the environment.

\begin{tabular}{|l|c|c|c|c|c|}
\hline \multicolumn{1}{|c|}{ Elesthetic } & $\begin{array}{c}\text { Masjid } \\
\text { Mahab } \\
\text { at } \\
\text { Khan }\end{array}$ & $\begin{array}{c}\text { Shiekh } \\
\text { Imam u din } \\
\text { Masjid }\end{array}$ & $\begin{array}{c}\text { Lwarrey } \\
\text { Jumat } \\
\text { (Wooden } \\
\text { Mosque) }\end{array}$ & $\begin{array}{c}\text { Ilyasi } \\
\text { Masjid }\end{array}$ & $\begin{array}{c}\text { Hazara } \\
\text { University } \\
\text { Jamia } \\
\text { Mosque }\end{array}$ \\
\hline $\begin{array}{l}\text { Geometric } \\
\text { Patterns }\end{array}$ & $\checkmark$ & $\checkmark$ & $\checkmark$ & $\checkmark$ & $\checkmark$ \\
\hline Calligraphy & $\checkmark$ & $\checkmark$ & $\checkmark$ & $\checkmark$ & $\begin{array}{c}\text { Very } \\
\text { limited use } \\
\text { (on } \\
\text { Exterior) }\end{array}$ \\
\hline Floral Patterns & $\checkmark$ & $\checkmark$ & $\checkmark$ & $\checkmark$ & Not Used \\
\hline Colored Glass & $\checkmark$ & $\checkmark$ & Not Used & $\checkmark$ & Not Used \\
\hline $\begin{array}{l}\text { Surface } \\
\text { ornamentation }\end{array}$ & $\checkmark$ & $\checkmark$ & $\checkmark$ & $\checkmark$ & $\checkmark$ \\
\hline Use of Water & $\checkmark$ & Not Used & Not Used & $\checkmark$ & $\begin{array}{c}\text { Not } \\
\text { Used }\end{array}$ \\
\hline
\end{tabular}

Table 02: Showing the Visual elements of the mosques 


\section{DISCUSSION}

The overall study of these selected cases suggested that there is present consistency in the use of the various architectural elements in the mosque architecture throughout history regarding the incorporation of the main building features of the mosques. The prayer hall, courtyard, veranda, either single or multiple Minar, Mehrab, and domes.

While the aesthetics elements are more site and environment-specific. As in Peshawar, use of the arches, decorated with relief work, niches in the dome for natural ventilation, a grand water tank in the middle of the courtyard, and generous openings are used to provide environmental efficacy. In Swat, the woodwork is reflecting the skilled craftsmanship of the area. The floral details are used to convey the love and passion of the craftsmen with religious enthusiasm. The Ilyasi masjid is also having elaborated carving in marbles, jali-work, and the minarets. The aesthetics elements of the Ilyasi masjid are influenced by the Islamic, British, and Sikh architecture, which is again area specific. The case of the Hazara University mosque is mostly reflecting the elements of the Arabic styles (Donor organization). But the use of the verandas on the three sides, use of the generous glass windows are always there to work in climatic conditions of the area.

\section{CONCLUSION}

In Khyber Pakhtunkhwa, mosque architecture has established traditions governing its selection and inclusion of architectural and aesthetic aspects. It has absorbed a variety of elements from geo-specific materiality, motifs, geometrical patterns, carvings, painting, and environmental responsiveness. The aesthetic features employed in mosques, particularly the mosque interiors, are responsible for the mosques' richness in design. When these components are integrated with the mosques' functional spaces, they can provide users with a complete blend of essentials and comfort. When the mosques' overall composition and architectural design consider the functional and spiritual needs of their users, the overall experience of the mosques improves dramatically. Second, based on the concept of simplicity and minimalism, this study argues that there is an inclination to overlook the aesthetic components of mosque architecture. However, it should be remembered that the aesthetic features are the only visual elements that enhance the mosque experience. Mosque decoration had to be a key component in meeting the users' psychological needs. It is a sign of our religious values, a means of maintaining direct contact with our creator through the use of Holy Quran verses, sophisticated geometric patterns, and 
the usage of the floral pattern to reflect the grandeur of paradise.

\section{RECOMMENDATIONS}

Rather than designing a structure that meets the prayer's spatial needs only, it is strongly advised that the mosque's architectural design be made more visually appealing and rich in experiential aspects.

There is also a pressing need to adhere to the basic guidelines listed below to improve the mosques' experiential qualities.

- We need to emphasize the functional, symbolic, and aesthetic values of Islamic architectural features.

- To provide skilled people from the region a chance to get together and demonstrate their religious fervor via their skills.

- Our society's art and craftsmanship must be revived and developed.

- The use of adornment in religious buildings should be revived.

- To attract the people through use of the elements of Islamic architecture.

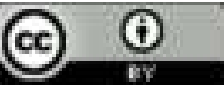

This work is licensed under a $\underline{\text { Creative Commons Attribution } 4.0 \text { International }}$ License.

\section{References:}

${ }^{1}$ Ali, I., \& Shah, M. W. The Significance of Islamic Architecture; The Case of First mosque in Madinah \& Contemporary Practices. Hazara Islamicus 2019(02).

${ }^{2}$ Kendra Weisbin, "Introduction to mosque architecture," in Smarthistory, August 8, 2015, accessed August 26, 2021, https://smarthistory.org/introduction-to-mosque-architecture/.

${ }^{3}$ Erzen, J. N. (2007). Islamic aesthetics: An alternative way to knowledge. The Journal of aesthetics and art criticism, 65(1), 69-75.

${ }^{4}$ Saniei, M., \& Delavar, A. (2012). Communicational role of mosques architecture. Asian Social Science, 8(3), 137.

${ }^{5}$ Mohammadi, M., \& Keramatifard, M. (2021). Philosophy of Aesthetics and Art in Islamic Architecture. International Journal of Multicultural and Multireligious Understanding, 8(2), 612-626.

${ }^{6}$ NASIM, S. UNUSUAL SHAPE, AND SIGNIFICANCE OF THE MIHTAB IN THE MODERN MOSQUE.

${ }^{7}$ Aghazadeh, M. (2018). Aesthetics and the Manifestation of Spirituality in Islamic-Iranian Art and Architecture with an Emphasis on Conceptual Symbols from the Perspective of Tourism. International Journal of Tourism \& Spirituality, 3(1), 26-56.

8 Shah, I. (1994). JĀMI'MASJID ANDARSHAHR 
COMMONLY KNOWN AS" MASJID MAHĀBAT KHĀN": THE QUESTION OF ATTRIBUTION. Islamic Studies, 33(4), 497-500.

${ }^{9}$ Qureshi, S. MAHABAT KHAN MOSQUE-AN ISLAMIC SYMBOL OF PEACE. Department of Architecture \& Planning, NED University of Engineering \& Technology, City Campus Maulana Din Muhammad Wafai Road, Karachi., 20.

${ }^{10}$ Harun Shuaib, "Ilyasi Mosque: A pearl in Abbottabad", posted in Youlin magazine on Aug 01,2019, accessed on 15 Aug 2021, https://www.youlinmagazine.com/article/ilyasi-mosque-a-pearl-inabbottabad/MTUyNw==

11 Fazal Khaliq, "Ancient mosque in Swat attracts lovers of art, architecture", in DAWN newspaper, June 9, 2017, accessed Aug 10, 2021, https://www.dawn.com/news/1338428/ancient-mosquein-swat-attracts-lovers-of-art-architecture

${ }^{12}$ Nader Buneri, “Sheikh Imam Uddin Mosque: One of oldest symbol of national heritage", published in The Nation, Feb 03,2020, accessed on Aug 16, 2021, https://nation.com.pk/03-Feb-2020/sheikhimam-uddin-mosque-one-of-oldest-symbol-of-national-heritage . 